\title{
What Triggers the Intention to Use the European Citizens' Initiative? \\ The Role of Benefits, Values and Efficacy
}

Anna Kandyla

Department of Political and Social Sciences

Sergiu Gherghina

European University Institute Florence

Department of Politics

University of Glasgow

\begin{abstract}
The European Citizens' Initiative (ECI) is a European Union instrument that aspires to encourage citizens to participate in EU policy-making. Although scholarly interest in the $\mathrm{ECl}$ is vivid, only isolated studies have examined the factors that shape the intention to use it. This article fills a gap in the literature by examining how personal benefits from the EU, value-based assessments of the EU, and political efficacy (internal and external) may trigger potential use of the ECI. It develops a model that is tested with recent Eurobarometer data. Results show that personal benefits from the $\mathrm{EU}$ are key determinants of the intention to use the $\mathrm{ECl}$ while considerations based on democratic values play a less important role. In addition, internal political efficacy emerges a strong predictor of potential use. The results challenge the expectation that the $\mathrm{ECl}$ could broaden public engagement with $\mathrm{EU}$ affairs.
\end{abstract}

Keywords: European Citizens' Initiative (ECI), personal benefits, democratic values, political efficacy, EU democratic deficit

\section{Introduction}

The European Citizens' Initiative (ECI) is a European Union (EU) instrument which allows European citizens to call on the European Commission (EC) to propose legislation on an issue, provided that the proposal is supported by at least one million signatures. The $\mathrm{ECl}$ is not a full-scale citizens' initiative since it lacks an immediate legislative effect or the possibility to be followed by a ballot vote. Instead, it is an agenda-setting tool that allegedly allows citizens to participate in shaping EU policy by enabling them to place their request at the start of the policy process. Between April 2012, when the ECl became operational, and October 2017, $47 \mathrm{ECls}$ have been launched, out of which four collected the required number of signatures. 
Much of the scholarly debate around the $\mathrm{ECl}$ takes place at a normative level with scholars discussing its implications for the emergence of a European public sphere (Warleigh-Lack 2007; Conrad 2016) and its potential to promote inclusive participation in EU political processes (Bouza Garcia \& Del Río Villar 2012; Monaghan 2012). The general view is that, despite limitations of design and weak potential to trigger legislation, the $\mathrm{ECl}$ could foster broader civic engagement with $\mathrm{EU}$ issues. Although the volume of the literature on the $\mathrm{ECl}$ is increasing and the instrument is being used, its relevance for Europe's citizens' remains uncharted. The currently available empirical research has mainly focused on profiling $\mathrm{ECl}$ organizers (Bouza Garcia and Greenwood 2014; Boussaguet 2016; Conrad and Steingrímsdóttir 2016) and only isolated studies have analysed the $\mathrm{ECl}$ from the perspective of the citizens (Kentmen-Cin 2014).

This paper attempts to fill this gap in knowledge by addressing the following question: who is likely to use the $\mathrm{ECl}$ and why? We argue that the intention to use the $\mathrm{ECl}$ depends on citizens' views of European integration and democracy and their skills related to EU politics. In particular, we claim that personal benefits from EU integration, associations of the EU with democratic values and sense of political efficacy (internal and external) increase the intention to use the $\mathrm{ECl}^{1}$ To test these hypotheses, the analysis relies on survey data from all EU Member States from two relatively recent Eurobarometer surveys.

\footnotetext{
${ }^{1}$ While we focus on motivating factors, we recognize that there are a few legal and financial hurdles which could inhibit the use of ECl. The study of such impediments goes beyond the purpose of this article mainly because these a) refer primarily to those who initiate $\mathrm{ECls}$ rather than to the citizens willing to sign them and $b$ ) there is limited awareness about them within the public. For a summary of these impediments see Ballesteros and Fiorentini (2015).
} 
Besides contributing to the discussion about the potential of the $\mathrm{ECl}$ with novel empirical evidence, the investigation pursued here bears broader implications. Political behaviour in the EU is mainly studied in relation to European Parliament (EP) elections and there is a dearth of research on participation beyond the representative channel. This is so despite the fact that instruments of direct citizen involvement in EU policy making processes have gotten prominence in academic and policy thinking as a solution to the democratic deficit for which the EU is notorious (Saurugger 2010). Available research, nonetheless, suggest that instruments directly involving citizens such as, for instance, public consultations fail to bring in large segments of the population and to attract citizens with diverse views and political positions (Hüller 2010; Kies and Nanz 2013). By assessing whether the ECl conforms to, or diverges from, these patterns this study advances knowledge on the prospects and limits of democratizing the EU through mechanisms of direct citizen participation. This is particularly acute in the context of the current challenges facing the legitimacy of the EU in the wake of the economic crisis (Fossum 2016, 5-8). By discussing, further, the analogies in terms of predispositions to participate in the $\mathrm{ECI}$ and EP elections, this article adds to the understanding of which citizens may embrace the opportunity to get involved in EU democratic processes more broadly.

The article is organized as follows. In the first section, we describe how the $\mathrm{ECl}$ works and develop the arguments and hypotheses. Next we discuss the methodology and present the data sources. The results of bivariate analyses and multivariate ordinal logistic regression models are presented in the third section. The conclusions discuss the major implications of this analysis and open avenues for further research. 


\section{Drivers of potential ECl use}

Any group of at least seven EU citizens can propose an $\mathrm{ECl}$, provided that a) the issue falls within the areas under the EC's right of legislative initiative for the purpose of implementing the Treaties and b) it is not contrary to the values of the Union. Compatibility with these requirements is subject to an eligibility check carried by the EC upon submission. To be successful, an $\mathrm{ECl}$ must collect within 12 months a minimum of one million signatures from at least seven Member States, with a minimum required amount of signatories per each of those States. ECls can be supported by any EU citizen old enough to vote in EP elections. Citizens can sign online or in paper format and should, depending on their nationality or country of residence, provide certified proof of identification. The organizers of ECls which successfully comply with all requirements are invited to present their $\mathrm{ECl}$ at a public hearing at the EP. The EC is subsequently mandated to examine the $\mathrm{ECl}$ in question and issue a public statement outlining an intended course of action, or alternatively, stating its reasons for none.

In spite of lacking a direct effect on legislation, the $\mathrm{ECl}$ is generally approached in the literature as an instrument which has some potential to broaden public engagement with EU affairs. For the most part, this interpretation departs from the expectation that the $\mathrm{ECl}$ could attract new constituencies of actors - by they citizens, civil society or social movements - who have been so far excluded from EU policy-making processes. Two arguments are mainly put forward to support this claim. First, it is expected that the $\mathrm{ECl}$ could appeal to those who contest EU integration and who put forward radical claims likely to capture public attention. 
Second, it is assumed that the ECl could activate the participation of 'ordinary' citizens in EU policy processes. We draw on the principal features of the ECI to appraise these expectations, arguing that the $\mathrm{ECl}$ seems to be more attractive to citizens who hold positive views of European integration and democracy and those who have skills related to EU politics. We propose a model which identifies personal benefits from EU integration, associations of the EU with democratic values, and political efficacy (internal and external) as crucial determinants of potential ECI use.

\section{Citizens' views of European integration and democracy and potential ECl use}

The expectations about the ECl's potential appeal to actors who contest EU integration originate in the assumption that the $\mathrm{ECl}$ differs in form and substance from other EU participatory mechanisms which tend to engage certain elite groups 'working in the interest of deeper integration' (Kohler-Koch 2010, 335). Firstly, in the $\mathrm{ECl}$ the EC does not have any control over the participants (Böttger and Plottka 2016, 22). Secondly, due to its agenda-setting character, the ECl could provide a channel for the expression of demands stemming from below, likely to interest the public more than do consultations and dialogue between professionalized groups and EU institutions (Bouza Garcia and Greenwood 2014). Efforts to mobilize the public across the EU could subsequently foster the emergence of transnational discursive spheres about specific issues (Knaut 2016). It has been argued that ECl campaigns could prompt debate on controversial EU issues past national angles (Conrad 2016), paving the way for the development of a transnational public sphere (Greenwood \& Tuokko 2017) and transnational democracy (Conrad 2011). 
Others, however, point out that the very format of the $\mathrm{ECl}$ seems to be limiting its use as a means for opposition against the EU (Raffenne 2015). First, the scope of eligible ECls is confined to calls for the EC to initiate legislation for the purpose of implementing the Treaties. ECl proposals which question the very framework of the EU tend, therefore, to be refused registration on the grounds that they fall outside the remit of the EC. It should be noted that all four ECls that were successful in terms of signatures contain claims which can be regarded as contentious (Bouza Garcia and Greenwood 2014). Thus, the Right 2 Water asks for legislation to secure water supply from privatization, One of Us requests the prohibition of EU spending on activities that involve the destruction of human embryos, Stop Vivisection asks to abrogate an EU directive concerning the use of animals for scientific purposes and Stop Glyphosate demands a ban on glyphosate. However, none of these implies an outright rejection of EU integration. Secondly, although the $\mathrm{ECl}$ can be organized bottom-up by citizens and other civic groups, it remains a top-down institutionalized process embedded in the EU's structures. By organizing, signing or supporting an $\mathrm{ECl}$ citizens direct their demands to $\mathrm{EU}$ institutions and policy makers. Use of the $\mathrm{ECl}$, hence, presupposes the acceptance of the EU as an appropriate level of governance.

There are reasons to expect that benefit-led explanations of EU acceptance and support (Gabel 1998) are particularly relevant when it comes to potential ECI use. These explanations have been applied to the study of participation in EP elections, where a positive link between turnout and perceptions of benefits accrued from the EU has been identified (Flickinger and Studlar 2007; Stockemer 2012). 
Abstention from EP elections may be conversely interpreted as an act of protest by citizens who consider that EU membership has failed to deliver any benefits.

As for participation in the $\mathrm{ECl}$, the only study on the subject finds no significant link between the perceptions of benefits from EU membership and the intention to use the ECI (Kentmen-Cin 2014). Using 2010 Eurobarometer survey data, the study concluded that the ECl was 'not yet a visible form of protest' (p. 314). While, however, evaluations of national benefits from EU membership rely on the assumption that individuals do indeed benefit from their country's membership, real-life benefits derived from the EU provide a direct measure for the actual implications of the EU on the citizen (Sigalas 2010). Intra-EU travellers, for instance, do not have to undergo border controls and, thanks to EU integration mobile EU citizens can reside freely within the EU. These tangible advantages brought by the integration of the EU are likely to generate acceptance of EU governance which, in turn, enhances the possibility that the $\mathrm{ECl}$ is seen in a positive light. On a practical dimension, quite a few ECls can be easily associated with the idea of direct benefits that EU citizens enjoy. For example, Fraternite 2020 aimed to enhance the benefit of free movement, i.e. calling for an expansion of EU exchange programmes. The ECI Single Communication Tariff Act aimed to end roaming fees across the EU, an idea integrated into the concept of the common market.

Moreover, the $\mathrm{ECl}$ is an instrument of limited formal power. Its potential legislative impact depends entirely on the support of EU institutions. According to the cost-benefit reasoning suggested by studies focusing on the rationality of participation in institutionalized politics (Blais 2000), a benefit-led analysis of the implications of participation may underpin potential ECl use. Costs relate to the 
resources allocated by citizens who organize an $\mathrm{ECl}$ or those who get informed about an existing $\mathrm{ECl}$ and sign it, providing the necessary proof of identification. Personal benefits from EU integration are likely to increase the expected value of using the $\mathrm{ECl}$, outweighing any such costs. Individuals who have personally benefited by the integration of the $\mathrm{EU}$ may find the $\mathrm{ECl}$ attractive because they consider that their participation can produce positive consequences. Our first hypothesis therefore reads as follows:

H1: The more benefits an individual has experienced from EU integration, the more likely it is that she or he will intend to use the ECI.

Value-based explanations seem to be equally relevant for understanding potential $\mathrm{ECl}$ use. The importance of evaluations of the political system in terms of democratic norms and values has been examined in relation to regime acceptance and legitimacy at the national level (Beetham 1994). Values such as freedom and the rule of law are commonly understood as essential components of democratic legitimacy (Gilley 2006). Associations of the political system with such values is subsequently shown to generate higher levels of political participation in so far as institutionalized democratic processes, such as the acts of voting or contacting government officials, are concerned (Norris 1999).

As to the EU, democratic values involving human rights and political equality are increasingly considered appropriate legitimation criteria alongside economic prosperity (Beetham \& Lord 1998). It is not surprising, therefore, that perceived correspondence of the EU with democratic values is shown to enhance perceptions 
of EU legitimacy (Ehin 2008). Research further indicates that the extent to which citizens in candidate countries embrace the value of the rule of law likewise increases the likelihood of accepting the EU as a political system that could compensate for flawed national institutions (Gherghina 2010). EU institutions themselves tend to underscore the contribution of the EU to the rule of law and emphasize the link between participation in EU politics and the democratization of the EU (McCormick 2010). Perceptions of regime legitimacy may, therefore, enhance participation at the $\mathrm{EU}$ level trough the $\mathrm{ECl}$ in the same way that they influence engagement with domestic politics. When citizens perceive the EU as a legitimate political system that functions according to democratic rules, they may consider that it can be improved through participation.

When looking closely at the issues addressed by some ECls, we can easily notice that democratic values are evoked. The example of the ECl Fraternité 2020 used before emphasizes the idea of solidarity among EU citizens which could be achieved through educational exchanges. The $\mathrm{ECl}$ Let me vote reflects this pursuit for equality, asking to grant EU citizens residing in another Member State the right to vote in all political elections in their country of residence on the same conditions as the nationals of that State. Two of the ECls that were successful in terms of signatures (Right 2 Water and Stop Glyphosate) have on the background values such as respect for human rights. We therefore expect that when citizens associate the EU with values related to the promotion and maintenance of democracy, such as rule of law, human rights and equality, they shall be more inclined to use the $\mathrm{ECl}$. The hypothesis is that: 
H2: The more an individual associates the EU with democratic values, the more likely it is that she or he will intend to use the ECl.

Previous research on the $\mathrm{ECl}$ emphasizes that citizens' attitudes towards democracy in the EU determine the intention to use this instrument (Kentmen-Cin 2014). It finds that citizens cynical about democracy in the EU are significantly less likely to intend to use the $\mathrm{ECl}$. Building on and extending this finding, we claim that belief in EU responsiveness in particular, referred to in the literature by the term 'external efficacy' (Balch 1974), enhances prospects for participation in the ECI. In normative terms, that political institutions be ready to respond to the preferences and needs of citizens constitutes a fundamental democratic principle (lyengar 1980). Perceptions of responsiveness are essential for political stability and, as such, they are associated with participation in domestic institutionalized politics (Hooghe \& Marien 2013). This link may also rest on a cost-benefit calculation: the more citizens believe that their interests are heard by the system the more confident they feel that participation can have the desired outcome. Within the setting of the EU, research indicates that citizens who perceive the EP as weak or unresponsive are more likely to abstain from EP elections (Clark 2014).

In the case of the $\mathrm{ECl}$, the dependence of legislative impact on institutional support renders external efficacy particularly relevant in explaining citizens' intention to use it. The ECl needs the positive attitude of EU institutions and, particularly, the receptivity of the EC. The idea about the responsiveness of institutions could form the basis of ECls which ask for an increase in EU competences with a view to enhancing the protection of specific rights and liberties. Telling is the 
case of the ECl on Media Pluralism, launched in 2013, which called for partial harmonisation of national rules with regard to the protection of media pluralism. Another example is the Minority SafePack - one million signatures for diversity in Europe $\mathrm{ECl}$, launched in 2017, which asks the EC to adopt legislation to improve the protection of persons belonging to national and linguistic minorities. In light of these theoretical arguments and empirical examples, we may expect that citizens who consider that EU policy-makers are generally responsive to citizens' demands will consider their participation effective. This leads to the following hypothesis:

H3: The more responsive an individual considers the EU to be, the more likely it is that she or he will intend to use the $\mathrm{ECI}$.

\section{Citizens' skills related to European politics and potential ECl use}

The second argument that has been advanced in support of the potential of the $\mathrm{ECI}$ to broaden public engagement with EU affairs focuses on the expectation that the $\mathrm{ECl}$ may facilitate the participation of 'ordinary' citizens in EU policy processes (Monaghan 2012). This expectation is placed in doubt by the very design of this instrument, which presents citizens with several challenges. The understanding of the EU's areas of competence required in order to prepare an $\mathrm{ECl}$ proposal is, for instance, hardly the property of ordinary citizens (Quittkat 2012). Indeed, recent analysis of $\mathrm{ECl}$ organizers has shown that these individuals are rather familiar with the complexity of EU politics (Boussaguet 2016). As to potential ECl signatories, although in practice the decision to support an $\mathrm{ECl}$ should be dependent on the precise issue that it addresses, an understanding of EU affairs and decision-making 
procedures seems fundamental. In the absence of common European media, exposure to information about on-going ECls will in all likelihood be confined to already active and politically sophisticated citizens (Bouza Garcia \& Del Río Villar 2012).

We will next evaluate these arguments by testing the impact of understanding of how EU politics works, in other words internal efficacy, on the intention to use the ECI. Internal efficacy, which has been extensively studied in relation to participation in domestic politics (Pollock 1983), was selected as the focus of analysis precisely because it captures the capacity- and motivation-dependent aspects of participation in the $\mathrm{ECl}$ highlighted above. Internal efficacy refers to the belief about one's own competence to understand politics and to participate effectively as a political actor (Miller 1974). Research suggests that internal efficacy correlates strongly with political knowledge (Niemi et al. 1991) and education (Jackson 1995) and is, therefore, associated with inequalities in political participation. Internal efficacy is also found to be determined by interest in politics (Craig \& Maggioto 1982). The mechanism seems to work as follows: increased political interest stimulates the search for information which, in turn, motivates participation. Within the setting of the EU, lack of familiarity with EU politics could translate into limited use of opportunities for participation that relate to EU policymaking (Baglioni \& Hurrelmann 2016). Applying these considerations to the $\mathrm{ECl}$, we hypothesize that:

H4: The better an individual understands how the EU works, the more likely she or he will intend to use the $E C l$. 


\section{Other antecedents of potential $\mathrm{ECl}$ use}

To avoid bias in the examination of the hypothesized relationships we control for other factors which could be associated with the intention to use the $\mathrm{ECI}$. These are explanatory factors for which we have no theoretical expectation due to either mixed evidence in previous research or to equivocal effects. First, satisfaction with the EU's democratic performance may influence the propensity to use the $\mathrm{ECl}$ (Kentmen-Cin 2014) or the two may run in parallel (Gherghina \& Groh 2016). Second, Eurosceptic attitudes may play a role in the willingness to use the $\mathrm{ECl}$, with potential effects going in different directions. On the one hand, those who oppose EU may refuse to get involved in the $\mathrm{ECI}$. On the other hand, as discussed earlier, critics of the European project might use the $\mathrm{ECl}$ to voice their disagreement with the course of EU integration. Third, political knowledge may also have an impact on the willingness to use the $\mathrm{ECl}$. Knowledge is an indicator of citizens' awareness about the possibilities for involvement in the decision-making process and sometimes this can create momentum for positive attitudes (Karp et al. 2003), i.e. willingness to use the $\mathrm{ECl}$. At the same time, awareness about the $\mathrm{EU}$ may instill a more reserved attitude towards the $\mathrm{ECl}$ because respondents understand the difficulty to influence such a complex structure of decision-making as the EU. Finally, level of education is also controlled for because it is positively associated with the intention to use the ECl (Kentmen-Cin 2014).

\section{Data and methods}


We test our hypotheses with data for all EU member states taken from two Eurobarometer surveys. This is the only public opinion survey which deals with the $\mathrm{ECl}$ and does so across countries. The first survey included in this analysis was conducted in May 2012 (EB79.3, in the aftermath of the ECl launch) and the second, in November 2013 (EB80.1). The latter is the most recent survey that contains the explanatory variables needed. The time interval between the two surveys allows us to observe whether the hypothesized relations change as this new instrument established itself and people grew accustomed to the idea. During the period covered by the data, more than 20 different $\mathrm{ECl}$ campaigns had been launched, gathering 5.5 million signatures in total (Berg \& Głogowski 2016). As no other Eurobarometer survey includes the same questions our analysis is limited to the investigated time frame. Another downfall related to data availability is the absence of questions regarding the awareness about the $\mathrm{ECl}$ and this is a cognitive component that can be hardly estimated through proxies. While the types of questions asked in the two surveys allow us to identify and compare statistical patterns, more nuanced explanations could not be considered.

The dependent variable is the intention to use the $\mathrm{ECl}$. Respondents were asked: 'The Lisbon Treaty came into force in December 2009. It has introduced the "European Citizens' Initiative". The initiative enables one million EU citizens to call on the European Commission to bring forward an initiative of interest to them in an area of EU competence. How likely or not do you think you would make use of this ECI?' Responses were coded on a four-point scale ranging from not at all likely (one) to very likely (four). Since this item refers to intended (future) use of the $\mathrm{ECl}$ it should be regarded as a modest predictor of actual behaviour. Moreover, it arguably lacks 
precision because it makes no distinction as to the possible forms of using the $\mathrm{ECI}$ (i.e. organizing, campaigning for, or signing an $\mathrm{ECl}$ ). However, no better measure is at the moment available.

The impact of personal benefits on the intention to use the $\mathrm{ECl}(\mathrm{H} 1)$ is measured with the question: 'For each of the following achievements of the EU, could you tell me whether you have benefited from it or not?' Respondents were presented with a list of achievements and answers were coded dichotomously. A cumulative index of responses relating to benefits from economic, political and social areas stemming from EU integration was created: border control, consumer rights, cheaper phone calls, medical assistance, and living/working/studying abroad. ${ }^{2}$ The index ranges from zero to five.

A second cumulative index measured the association of the EU with democratic values (H2). Respondents were asked: 'In the following list, which values best represent the EU?' The index included rule of law, human rights, democracy, equality and solidarity. These values were selected because they are integrated within the EU's democratic narrative (Biegon 2013). ${ }^{3}$ The index ranges from zero to five.

To measure perceptions of EU responsiveness $(\mathrm{H} 3)$ we relied on the question asking respondents to what extent they agree or disagree with the statement 'my voice counts in the EU' $(\mathrm{H} 3)$. In line with previous research (Braun \& Tausendpfund 2014), the ability to understand EU politics, that is, internal efficacy (H4), is

\footnotetext{
${ }^{2}$ While the questionnaire presents a broader range of benefits, we selected these benefits because they a) correspond to different areas of life and, b) exhibit variation. Working, living and studying were put together because they refer to the same benefit (freedom of movement).

${ }^{3}$ The questionnaire includes a broader list of values. The selection of values was based on theoretical considerations and methodological concerns such as the existence of variation.
} 
measured with a question asking respondents to indicate whether they agree or disagree with the statement 'I understand how the EU works'. Responses to these questions range from one (totally disagree) to four (totally agree).

The control variables are operationalized as follows. For measuring satisfaction with the EU's democratic performance we used the question asking respondents to what extent they are satisfied with the way democracy works in the EU. Responses range from one (not at all satisfied) to four (very satisfied). Eurosceptic attitudes are measured through two indicators: attachment to the EU and satisfaction with the direction in which the EU goes. For the former we relied on the question 'How attached do you feel to the EU?' (one being 'not attached at all', to four being 'very attached') and for the latter on the question: 'At the present time, would you say that, in general, things are going in the right direction or in the wrong direction, in the EU?'. Political knowledge is measured with an index of responses to three objective knowledge questions on the EU and level of education is measured by age of completion of formal education. ${ }^{4}$

The empirical part of the study is structured along bivariate and multivariate statistical analyses. ${ }^{5}$ Since all variables are ordinal we use non-parametric correlations (Spearman) and ordered logistic regression. Moreover, since the distribution is skewed (see Figure 1), we considered it appropriate to use standard errors.

\footnotetext{
${ }^{4}$ The question reads: 'For each of the following sentences about the EU, could you please tell me whether you think it is true or false?' (1) 'The EU consists of (the correct number of) member states', (2) 'The Members of the EP are directly elected by the citizens of each Member State' and (3) 'Switzerland is a member of the EU' (correct answers = one, incorrect answers and 'do not know' = zero). Other controls such as sex, age and nationality were not included because previous model specifications showed minor effects.

${ }^{5}$ We tested for multi-collinearity among all independent variables and the results indicate that this is not a problem. The highest correlation is $0.42 * *$ between assessments of the direction in which the EU goes and satisfaction with democracy in the EU in 2013 survey.
} 


\section{Findings}

We start by looking at some descriptive statistics on the likely use of the $\mathrm{ECl}$ across the EU. Figure 1 presents the distribution of responses on the intention to use the $\mathrm{ECl}$ with bars reflecting percentages. Overall, there is a public reluctance towards the use of the $\mathrm{ECl}$. In both surveys, three out of four respondents report that it is not at all, or not very likely, to use the $\mathrm{ECl}$. With the exception of a slight increase in the percentage of citizens who report that it is not at all likely to use the $\mathrm{ECl}$ in 2013 , a relative stability in public preferences across the two surveys is noted. This stability could be an indicator of the poor visibility of the ECl or, perhaps, of its limited potential of action. Nonetheless, the $\mathrm{ECl}$ does attract some interest among $\mathrm{EU}$ citizens, with one in four respondents consistently saying that they are fairly likely to use it and 5 per cent declaring a high likelihood to use it in both surveys.

\section{[FIGURE 1 ABOUT HERE]}

Table 1 displays the bivariate correlations between the intention to use the $\mathrm{ECl}$ and the explanatory variables for each of the two EB surveys. Overall, the results provide support for all four hypotheses, significant at the highest level of confidence. Both in 2012 and 2013, the highest correlation emerges between the intention to use the $\mathrm{ECl}$ and personal benefits brought by the EU (H1). The correlation between associations of the EU with democratic values and declared intention to use the $\mathrm{ECI}$ is weaker. Both perceptions of EU responsiveness (external efficacy, H3) and understanding of how the EU works (internal efficacy, $\mathrm{H} 4$ ) correlate strongly with the declared intention to use the $\mathrm{ECl}$. Finally, the control variables correlate positively with the intention to use the $\mathrm{ECl}$, all relationships being significant at the 0.01 level. 
Attachment to the $\mathrm{EU}$ correlates highly with the intention to use the $\mathrm{ECl}$, its strength being preceded only by that of benefits.

\section{[TABLE 1 ABOUT HERE]}

The results of the multivariate statistical models are presented in Table 2. For each survey we estimate a main effects model (Model 1 ) and a full model which includes the control variables (Model 2). One general observation is that the effect size and the direction of the effect of the explanatory variables are fairly similar in the two surveys. All hypothesized effects are statistically significant at the 0.01 level of confidence. A second observation is that the inclusion of the control variables neither renders any of the four predictors statistically insignificant, nor improves the fit of the models (the value of the pseudo $\mathrm{R}^{2}$ is fairly similar in the two Models).

The results for the full models show that all hypothesized predictors have a statistically significant positive effect on the intention to use the $\mathrm{ECl}$. We find that personal benefits from the EU are associated with a higher probability to make use of the $\mathrm{ECl}$, as anticipated by $\mathrm{H} 1$, controlling for other antecedents. Consistent with $\mathrm{H} 2$, results show a positive link between association of the $\mathrm{EU}$ with values and intention to use the $\mathrm{ECl}$ which is, nonetheless, smaller to that of benefits. In line with $\mathrm{H} 3$, citizens who believe that the $\mathrm{EU}$ is responsive are more likely to use the $\mathrm{ECl}$. Finally, the measure of internal efficacy also has a positive and statistically significant association with the intention to use the $\mathrm{ECl}(\mathrm{H} 4)$ which is substantive in term of size.

As to the control variables, attachment to the EU has a positive and statistically significant impact on the intention to use the $\mathrm{ECl}$, larger, in fact, than that of the explanatory variables. Intention to use the $\mathrm{ECl}$ also increases with education as one would expect. For both variables the size of the effect is almost 
identical in the two surveys. The other control variables show no consistent statistically significant effect.

\section{[TABLE 2 ABOUT HERE]}

To gain a better understanding of the magnitude of the effects of the two explanatory variables which seem to be strongly associated with the intention to use the $\mathrm{ECl}$, that is personal benefits from the $\mathrm{EU}$ and understanding how the $\mathrm{EU}$ works, marginal effects were calculated. Figure 2 presents the results for the two surveys. The solid line shows the marginal effect, and the grey area indicates a 95 per cent confidence interval based on the estimates of the models reported in Table 1. The results of the two surveys are quite similar. Keeping everything else constant, when respondents report to have benefited from one additional EU policy, the predicted probability of using the $\mathrm{ECl}$ increases by roughly 0.15 . The marginal effect of internal efficacy on predicting the probability of using the $\mathrm{ECl}$ is stronger: intention to use the $\mathrm{ECl}$ increases at a higher rate (by 0.2 ) when respondents display a better understanding of how the EU works.

\section{[FIGURE 2 ABOUT HERE]}

\section{Conclusions}

This article sought to identify and explain the factors that encourage the intention to use the $\mathrm{ECl}$. Our analysis examined the role played by utilitarian considerations, assessments of the EU in terms of democratic values and internal and external political efficacy when it comes to potential use of the ECI. Three major results stand out. First, we show that European citizens are far from excited with the ECl. This observation is consistent across the two surveys used and may explain the ECl's low rate of success in collecting signatures with only four out of 47 making it. That the 
$\mathrm{ECl}$ may engage only a small fraction of citizens goes against the principles on which this instrument has allegedly been introduced, i.e. to broaden civic engagement with EU affairs. For the limited public interest in the $\mathrm{ECl}$, activists point to EU institutions and mainstream media. The former have done little to advertise the $\mathrm{ECl}$ while the latter tend to be either unaware of the $\mathrm{ECl}$ or misinformed (Berg and Thomston $2015,122)$. Against this background, the campaign efforts of $\mathrm{ECl}$ organizers may not suffice to stimulate interest in this new instrument. The $\mathrm{ECl}$ seems, therefore, to suffer from one of the problems it seeks to address, namely the lack of a transnational public sphere.

Second, the results suggest that utilitarian considerations with respect to the $\mathrm{EU}$ are key determinants of the intention to use the $\mathrm{ECI}$. These findings can be seen through the lenses of a cost-benefit analysis. Costs include the time to get informed about the initiative and the low likelihood to achieve the desired outcomes considering the ECl's weak policy impact. Individuals who have reaped more benefits from EU integration have a higher expected value of the $\mathrm{ECl}$, outweighing the costs of participation. Since the dependent variable includes modes of ECl use which involve different costs (the costs of organizing an $\mathrm{ECl}$ are substantively higher than simply supporting one), the size of the effect of benefits should be considered with caution. However, the intention to use the $\mathrm{ECl}$ is not exclusively utilitarian: associations of the EU with key democratic values and perceptions of EU responsiveness also have a positive, though smaller, effect. The motivating role of democratic values is consistent with literature on regime acceptance and legitimacy while the impact of external efficacy is justified by reference to the reliance of the $\mathrm{ECl}$ on institutional support. Third, the findings demonstrate that citizens' skills 
related to EU politics are crucial when it comes to participation in the $\mathrm{ECl}$. The $\mathrm{ECl}$ seems considerably more appealing to a particular set of citizens: the politically sophisticated who feel able to navigate the complexity of EU politics.

This study has implications that are relevant for EU scholars and EU policymakers by contributing new knowledge to the broader debate on citizen participation in EU decision-making processes. It does so in two ways. It shows: a) that contrary what is expected in the literature and feared by EU leaders (Berg 2016) the $\mathrm{ECl}$ does not appeal to actors which contest $\mathrm{EU}$ integration and b) that the $\mathrm{ECl}$ is not likely to contribute to diminishing the democratic deficit by engaging either the sceptic or the 'ordinary' EU citizen.

Firstly, it is clear that the intention to use the $\mathrm{ECl}$ is driven by positive evaluations of the EU: benefit-provider, polity characterized by adherence to democratic values and responsiveness. These observations are related to the character of the $\mathrm{ECl}$ and suggest that the $\mathrm{ECl}$ is, in principle, not an instrument for individuals and groups who contest the EU's political system or desire less economic and political integration. That the $\mathrm{ECl}$ is unlikely to act as a protest mechanism is further supported by the positive link between attachment to Europe and intention to use the $\mathrm{ECl}$. While the $\mathrm{ECl}$ could be (and has been) used as a vehicle to express dissatisfaction with EU policies, it does so in a manner that contributes to solution finding. For example, the ECls Stop Vivisection and One of Us sought to repeal existing EU legislation fostering thereby 'citizens' ownership and "normalisation" of the EU, that is the possibility to contest its polices without contesting the polity' (Bouza Garcia \& Del Río Villar 2012). Despite its constrained contestation potential, the $\mathrm{ECl}$ may still bear some deliberative consequences which are conducive to the 
development of transnational democracy (Conrad 2016). It could do so by functioning as a channel for connecting existing issue-discursive spaces (Knaut 2016) especially through the internet and social media (Polchow 2016).

Secondly, it seems unlikely that the $\mathrm{ECl}$ can decrease the democratic deficit of the EU through engaging diverse audiences. The ECl's appeal is confined to a group of citizens who already have confidence in the responsiveness of the EU's political system rather than those who feel alienated from EU political processes. The evidence presented about the importance of citizens' skills speaks further about the limits of the $\mathrm{ECl}$ from a democratic point of view, confirming earlier findings on the subject (Kentmen-Cin 2014; Gherghina and Groh 2016). It seems that lack of familiarity with EU politics translates into lack of will to embrace mechanisms of participation at the EU level such as the $\mathrm{ECI}$. In practice, the topics of ECls may reflect some knowledge about what integration entails. To refer specifically to the ECls that are collecting signatures at the time of writing, two are on European citizenship (EU Citizenship for Europeans and Retaining European Citizenship) and two refer to EU citizen rights (European Free Movement Instrument and Minority SafePack - one million signatures for diversity in Europe). EU policy makers concerned with the EU's deficit may take our findings into consideration when revising the $\mathrm{ECl}$ regulation (scheduled for 2018) and devising the EU's broader communication strategy. Efforts to increase public understanding of how the EU functions could, perhaps, prove beneficial for stimulating direct citizen participation in EU policy-making.

For scholars of political participation in the EU these findings are useful from both a theoretical and an empirical perspective. Our study is the first to address the relevance of evaluations of the $\mathrm{EU}$ in terms of democratic values for political 
participation at the EU level. The finding indicates that citizens care about the democratic credentials of the EU and take them into account when evaluating the prospects of getting involved. The study, further, implies that participation in the $\mathrm{ECl}$ conforms to what is known for other, non-electoral and electoral, EU level processes, at least as regards the diversity of the participants' views about the EU. Notably, since the $\mathrm{ECl}$ is not likely to be employed as a form of protest, the comparability with EP elections seems to be greater than perhaps anticipated. From an empirical perspective, the $\mathrm{ECI}$ may be included in broader models of political participation next to EP elections. Moreover, the variables used are not context-sensitive and they may be replicated whenever data becomes available to test the robustness of these results. Finally, knowing that the likely $\mathrm{ECl}$ users are in fact supporters of the European project is potentially useful for future $\mathrm{ECl}$ organizers as they can design their campaigns accordingly in order to maximize their appeal.

This study has several shortcomings that merit attention. First, due to questionnaire constrains, the dependent variable taps the intention to use the $\mathrm{ECI}$ rather than actual use and crucially, it does not allow for a distinction between different forms of $\mathrm{ECl}$ use. Future research should improve the measurement and allow a distinction between initiating an $\mathrm{ECl}$ and signing one to be made. Moreover, the inclusion of questions that address respondents' awareness of the $\mathrm{ECl}$ needs to be considered because people who are aware of the $\mathrm{ECI}$ might evaluate it differently than those not familiar with it. 


\section{Acknowledgements}

We are deeply grateful to the four anonymous JCMS reviewers for their very helpful comments on earlier versions of the article. We would also like to thank the organizers and the participants of both the Europa Research Group seminar (University of Edinburgh) and the panel '5 Years European Citizens' Initiative (ECl) Dying Patient or Bright Future Ahead? Empirical Perspectives on the Use and Impact of the ECl' of the ECPR conference in Prague (September 2016) for their valuable comments on earlier drafts. 


\section{List of References:}

Baglioni, S. and Hurrelmann, A. (2016) 'The Eurozone Crisis and Citizen Engagement in EU Affairs'. West European Politics, Vol. 39, No. 1, pp. 104-24.

Balch, G. I. (1974) 'Multiple Indicators in Survey Research: The Concept "Sense of Political Efficacy"'. Political Methodology, Vol. 1, No. 2, pp. 1-43.

Ballesteros, M., and Fiorentini, S. (2015) 'Towards a Revision of the European Citizens' Initiative?' European Parliament.

http://www.europarl.europa.eu/RegData/etudes/STUD/2015/519240/IPOL_STU(20 15)519240_EN.pdf.

Beetham, D., (ed.) (1994) Defining and Measuring Democracy (London; Thousand Oaks, Calif: Sage Publications).

Beetham, D. and Lord, C. (1998) Legitimacy and the EU (London: Longman).

Berg, C. (2016) 'Commission Ignoring the ECl's Positive Potential for Democracy'. Euractiv, 2016. https://www.euractiv.com/section/eu-priorities-2020/opinion/commissionignoring-the-eci-s-positive-potential-for-democracy/.

Berg, C. and Głogowski, P. (2016) 'Heavy Stones in the Road: The ECl in Practice'. In M. Conrad, A. Knaut, and K. Böttger (eds) Bridging the Gap? Opportunities and Constraints of the European Citizens' Initiative (Europäische Schriften / Institut Für Europäische Politik. Baden-Baden: Nomos), pp.219-22.

Berg, C. and Thomston, J. (2015) 'Tips for ECl Campaigns from An ECl That Works!' The ECI Campaign. http://www.citizens-initiative.eu/wpcontent/uploads/2015/01/Tips_For_ECl_Campaings.pdf.

Biegoń, D. (2013) 'Specifying the Arena of Possibilities: Post-Structuralist Narrative Analysis and the European Commission's Legitimation Strategies'. JCMS: Journal of Common Market Studies, Vol. 51, No. 2, pp. 194-211.

Blais, A. (2000) To Vote Or Not to Vote?: The Merits and Limits of Rational Choice Theory (Pittsburgh: University of Pittsburg Press).

Böttger, K. and Plottka, J. (2016) 'The ECl - An Overview of Opportunities and Constraints'. In M. Conrad, A. Knaut, and K. Böttger (eds) Bridging the Gap? Opportunities and Constraints of the European Citizens' Initiative (Europäische Schriften/Institut Für Europäische Politik. Baden-Baden: Nomos), pp. 16-46.

Boussaguet, L. (2016) 'Participatory Mechanisms as Symbolic Policy Instruments?'. Comparative European Politics, Vol. 14, No. 1, pp. 107-24.

Bouza Garcia, L. and Greenwood, J. (2014) 'The European Citizens' Initiative: A New Sphere of EU Politics?'. Interest Groups \& Advocacy, Vol. 3, No 3, pp. 246-67.

Bouza Garcia, L. and Del Río Villar, S. (2012) 'The ECl as a Democratic Innovation: Analysing Its Ability to Promote Inclusion, Empowerment and Responsiveness in European Civil Society'. Perspectives on European Politics and Society, Vol. 13, No. 3, pp. 312-24.

Braun, D. and Tausendpfund, M. (2014) 'The Impact of the Euro Crisis on Citizens' Support for the European Union'. Journal of European Integration, Vol. 36, No. 3, pp. 231-45.

Clark, N. (2014) 'Explaining Low Turnout in European Elections: The Role of Issue Salience and Institutional Perceptions in Elections to the European Parliament'. Journal of European Integration, Vol. 36, No. 4, pp. 339-56.

Conrad, M. (2011) 'The European Citizens' Initiative: Transnational Democracy in the EU at Last?'. Icelandic Review of Politics \& Administration, Vol. 7, No 1, p. 5.

Conrad, M. (2016) 'The ECl's Contribution to the Emergence of a European Public Sphere'. In M. Conrad, A. Knaut, and K. Böttger (eds) Bridging the Gap? Opportunities and Constraints of the European Citizens' Initiative (Europäische Schriften/ Institut Für Europäische Politik. Baden-Baden: Nomos), pp. 64-80. 
Conrad, M. and Steingrímsdóttir F. (2016) 'A Tool for European Citizens? A Typology of ECI Organizers 2012-2015'. In M. Conrad, A. Knaut, and K. Böttger (eds) Bridging the Gap? Opportunities and Constraints of the European Citizens' Initiative (Europäische Schriften/ Institut Für Europäische Politik. Baden-Baden: Nomos), pp. 112-27.

Craig, S. and Maggioto, M. A. (1982) 'Measuring Political Efficacy'. Political Methodology, Vol. 8, No.3, pp. 85-109.

Ehin, P. (2008) 'Competing Models of EU Legitimacy: The Test of Popular Expectations'. JCMS: Journal of Common Market Studies, Vol. 46, No. 3, pp. 619-40.

Flickinger, R.S. and Studlar D.T. (2007) 'One Europe, Many Electorates?' Comparative Political Studies, Vol. 40, No. 4, pp.383-404.

Fossum, J.E. (2016) 'Democracy and Legitimacy in the EU: Challenges and Options'. IAI Working Papers 16/01. http://www.iai.it/sites/default/files/iaiwp1601.pdf.

Gabel, M. (1998) 'Public Support for European Integration: An Empirical Test of Five Theories'. The Journal of Politics, Vol 60, No. 2, pp. 333-54.

Gherghina, S. (2010) 'Unraveling Romance: An Assessment of Candidate Countries' Support for the EU'. Comparative European Politics, Vol. 8, No.4, pp. 444-67.

Gherghina, S. and Groh, A. (2016) 'A Poor Sales Pitch? The European Citizens' Initiative and Attitudes toward the EU in Germany and the UK'. European Politics and Society, Vol. 17, No. 3, pp. 373-87.

Gilley, B. (2006) 'The Determinants of State Legitimacy: Results for 72 Countries'. International Political Science Review, Vol. 27, No 1, pp. 47-71.

Greenwood, J. and Tuokko, K. (2017). 'The European Citizens' Initiative: The Territorial Extension of a European Political Public Sphere?'. European Politics and Society, Vol. 18 , No. 2, pp.166-81.

Hooghe, M. and Marien, S. (2013) 'A Comparative Analysis of the Relation between Political Trust and Forms of Political Participation in Europe'. European Societies, Vol. 15, No. 1, pp. 131-52.

Hüller, T. (2010) 'Playground or Democratisation? New Participatory Procedures at the European Commission'. Swiss Political Science Review, Vol. 16, No 1, pp. 77-107.

lyengar, S. (1980) 'Subjective Political Efficacy as a Measure of Diffuse Support'. Public Opinion Quarterly, Vol. 44, No. 2, pp. 249-56.

Jackson, R. A. (1995) 'Clarifying the Relationship Between Education and Turnout'. American Politics Quarterly, Vol. 23, No.3, pp. 279-99.

Karp, J.A., Banducci, S.A. and Bowler, S. (2003) 'To Know It Is to Love It? Satisfaction with Democracy in the European Union'. Comparative Political Studies, Vol 36, No. 3, pp. 271-92.

Kentmen-Cin, C. (2014) 'Explaining Willingness to Use the European Citizens' Initiative: Political Cynicism, Anti-EU Attitudes and Voting Weight of Member States'. Comparative European Politics, Vol. 12, No 3, pp. 301-18.

Kies, R. and Nanz P. (eds) (2013) Is Europe Listening to Us? Successes and Failures of EU Citizen Consultations (Farnham, Surrey: Ashgate).

Knaut, A. (2016) 'Rethinking the Imaginary of the Public Sphere: Transnational Discursive Spheres and the $\mathrm{ECl}^{\prime}$. In M. Conrad, A. Knaut, and K. Böttger (eds) Bridging the Gap? Opportunities and Constraints of the European Citizens' Initiative (Europäische Schriften/ Institut Für Europäische Politik. Baden-Baden: Nomos), pp. 47-63.

Kohler-Koch, B. (2010) 'Civil Society and the European Union'. In Helmut K. and Toepler, S. (eds) International Encyclopedia of Civil Society (New York: Springer), pp. 332-38.

McCormick, J. (2010) Europeanism (Oxford; New York: Oxford University Press).

Miller, A. H. (1974) 'Political Issues and Trust in Government: 1964-1970'. American Political Science Review, Vol. 68, No 3, pp. 951-72. 
Monaghan, E. (2012) 'Assessing Participation and Democracy in the EU: The Case of the European Citizens' Initiative'. Perspectives on European Politics and Society, Vol.13, No. 3, pp. 285-98.

Niemi, R., Craig, S. and Mattei, F. (1991) 'Measuring Internal Political Efficacy in the 1988 National Election Study'. The American Political Science Review, Vol. 85, No 4, pp. 1407-13.

Norris, P. (1999) 'Conclusions: The Growth of Critical Citizens and Its Consequences'. In Norris P. (ed.) Critical Citizens: Global Support for Democratic Government (Oxford University Press), pp. 57-272.

Polchow, Y. (2016) 'The ECl in Social Media: Transnational Discursive Spaces in the Making?' In M. Conrad, A. Knaut, and K. Böttger (eds) Bridging the Gap? Opportunities and Constraints of the European Citizens' Initiative (Europäische Schriften/ Institut Für Europäische Politik. Baden-Baden: Nomos), pp. 128-48.

Pollock, P. H. (1983) 'The Participatory Consequences of Internal and External Political Efficacy: A ResearchNote'. The Western Political Quarterly, Vol. 36, No. 3, pp. 400409.

Quittkat, C. (2012) 'Die EBI - (K)Ein Tor Zur Europäischen Politik Für "Normalbürger". Forschungsjournal Soziale Bewegungen, Vol. 25, No 4, pp. 69-79.

Raffenne, C. (2015) 'The European Citizens' Initiative: The Influence of Anglo-American Governance Ideology on Recent EU Institutional Reforms'. In Avril, E. and Neem, J.N. (eds) Democracy, Participation and Contestation : Civil Society, Governance and the Future of Liberal Democracy (Abingdon, Oxon; New York, NY: Routledge), pp. 15467.

Saurugger, S. (2010) 'The Social Construction of the Participatory Turn: The Emergence of a Norm in the European Union'. European Journal of Political Research, Vol. 49, No. 4, pp. 471-95.

Sigalas, E. (2010) 'The Role of Personal Benefits in Public Support for the EU: Learning from the Erasmus Students'. West European Politics, Vol. 33, No 6, pp. 1341-61.

Stockemer, D. (2012) 'Citizens' Support for the European Union and Participation in European Parliament Elections'. European Union Politics, Vol. 13, No 1, pp. 26-46.

Warleigh-Lack, A. (2007) 'On the Path to Legitimacy? The EU Citizens Initiative Right from a Critical Deliberativist Perspective'. In Ruzza, C. and Della Sala, V. (eds) Governance and Civil Society in the European Union (Manchester; New York: Manchester University Press), pp. 55-72. 
Figures

Figure 1: The intention of EU citizens to use the $\mathrm{ECl}$



Figure 2: Marginal effects of benefits and internal efficacy on the intention to use the $\mathrm{ECl}$

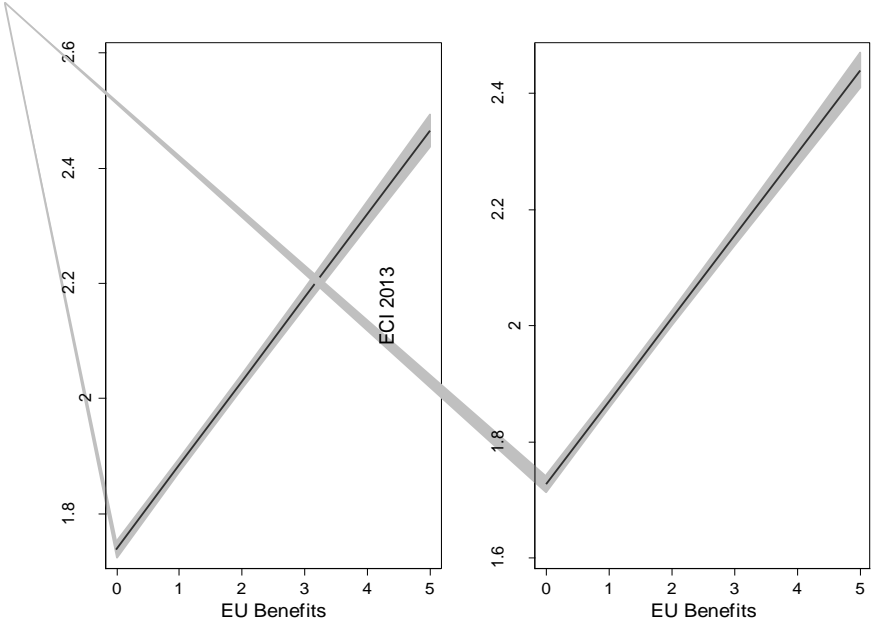



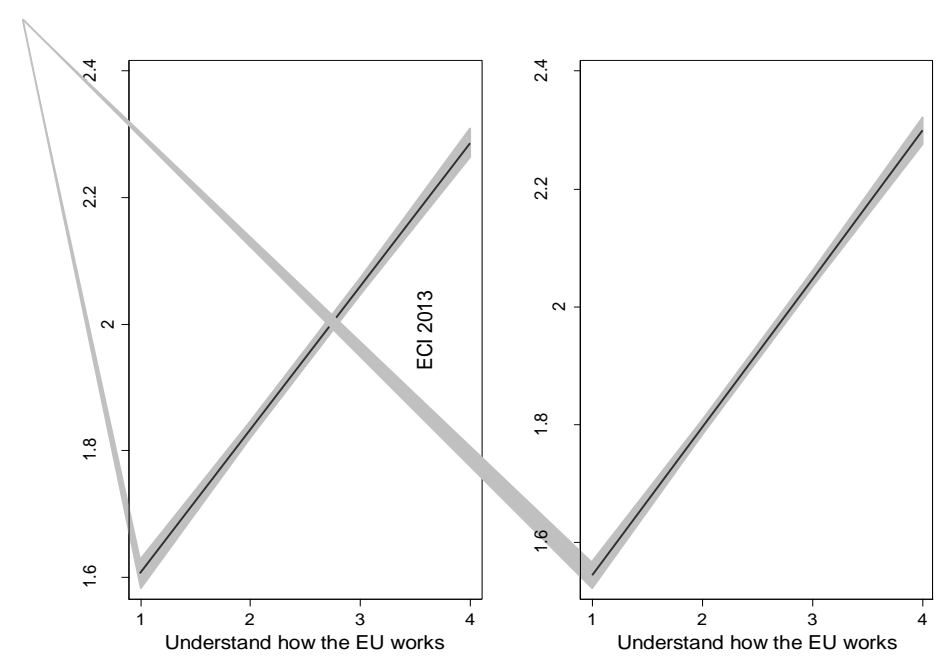

Tables

Table 1: Bivariate correlations between intention to use the $\mathrm{ECl}$ and other variables

\begin{tabular}{lcc}
\hline Variables & May 2012 & $\begin{array}{c}\text { November } \\
\mathbf{2 0 1 3}\end{array}$ \\
\hline EU benefits & $0.28^{* *}$ & $0.25^{* *}$ \\
EU values & $0.12^{* *}$ & $0.14^{* *}$ \\
Voice counts in the EU & $0.20^{* *}$ & $0.19^{* *}$ \\
Understand how the EU works & $0.22^{* *}$ & $0.23^{* *}$ \\
\hline EU democracy satisfaction & $0.13^{* *}$ & $0.15^{* *}$ \\
EU attachment & $0.24^{* *}$ & $0.24^{* *}$ \\
EU right direction & $0.10^{* *}$ & $0.11^{* *}$ \\
Knowledge about the EU & $0.12^{* *}$ & $0.11^{* *}$ \\
Education & $0.16^{* *}$ & $0.17^{* *}$ \\
\hline $\mathrm{N}$ & $20,696-23,522$ & $22,773-25,302$ \\
\hline
\end{tabular}

Notes: Reported coefficients are non-parametric (Spearman). $\mathrm{N}$ differs across questions due to missing values

** significant at $\mathrm{p}<0.01{ }^{*}$ significant at $\mathrm{p}<0.05$. 
Table 2: Ordinal logistic regression on the intention to use the ECI

\begin{tabular}{|c|c|c|c|c|}
\hline \multirow[t]{2}{*}{ Variables } & \multicolumn{2}{|c|}{ May 2012} & \multicolumn{2}{|c|}{ November 2013} \\
\hline & Model 1 & Model 2 & Model 1 & Model 2 \\
\hline \multirow[t]{2}{*}{ EU benefits } & $1.29 * *$ & $1.23 * *$ & $1.25^{* *}$ & $1.20 * *$ \\
\hline & $(0.01)$ & $(0.01)$ & $(0.01)$ & $(0.01)$ \\
\hline \multirow[t]{2}{*}{ EU values } & $1.10 * *$ & $1.04^{*}$ & $1.17^{* *}$ & $1.10^{* *}$ \\
\hline & $(0.02)$ & $(0.02)$ & $(0.02)$ & $(0.02)$ \\
\hline \multirow[t]{2}{*}{ Voice counts in the EU } & $1.25 * *$ & $1.13^{* *}$ & $1.20 * *$ & $1.10 * *$ \\
\hline & $(0.02)$ & $(0.02)$ & $(0.02)$ & $(0.02)$ \\
\hline \multirow[t]{2}{*}{ Understand how the EU works } & $1.39 * *$ & $1.25^{* *}$ & $1.46^{* *}$ & $1.33^{* *}$ \\
\hline & $(0.03)$ & $(0.03)$ & $(0.03)$ & $(0.03)$ \\
\hline \multirow[t]{2}{*}{ EU democracy satisfaction } & & 0.97 & & 1.01 \\
\hline & & $(0.02)$ & & $(0.02)$ \\
\hline \multirow[t]{2}{*}{ EU attachment } & & $1.35^{* *}$ & & $1.32 * *$ \\
\hline & & $(0.03)$ & & $(0.03)$ \\
\hline \multirow[t]{2}{*}{ EU right direction } & & $1.06 * *$ & & 1.00 \\
\hline & & $(0.02)$ & & $(0.02)$ \\
\hline \multirow[t]{2}{*}{ Knowledge about the EU } & & 1.03 & & 1.02 \\
\hline & & $(0.02)$ & & $(0.02)$ \\
\hline \multirow[t]{2}{*}{ Education } & & $1.17^{* *}$ & & $1.17^{* *}$ \\
\hline & & $(0.03)$ & & $(0.03)$ \\
\hline $\mathrm{N}$ & 19,534 & 15,488 & 21,729 & 17,473 \\
\hline Pseudo $R^{2}$ & 0.05 & 0.05 & 0.04 & 0.05 \\
\hline Wald $\mathrm{Chi}^{2}$ & 2096.89 & 1671.62 & 2266.51 & 1844.31 \\
\hline
\end{tabular}

Notes: Reported coefficients are odds-ratios, robust standard errors in brackets.

** significant at $\mathrm{p}<0.01$ * $^{*}$ significant at $\mathrm{p}<0.05$ 